\title{
Phenotypic analysis of breast cell lines - triple negative cells vs expressing hormonal receptors
}

\author{
Mafalda Laranjo ${ }^{1,4^{*}}$, Maria J Carvalho ${ }^{2,4}$, Artur Paiva ${ }^{3,4}$, A Margarida Abrantes ${ }^{1,4}$, Isabel Torgal ${ }^{2,4}$, Carlos F Oliveira ${ }^{4}$, \\ M Filomena Botelho ${ }^{1,4}$
}

From 16th International Charles Heidelberger Symposium on Cancer Research

Coimbra, Portugal. 26-28 September 2010

Breast cancer patients are stratified in 3 groups: expressing hormonal receptors (HR), which respond to therapies targeting estrogen receptors; HER2+, candidates to trastuzumab; and triple negative (TN), for which, despite its more aggressive clinical behavior, chemotherapy is therapy available.

In vitro studies proved that cells subjected to specific growth factors form spherical colonies of stem-cells in suspension designated mammospheres (MS). The aim of this work is to assess the capacity to form MS in TN (HCC1806) comparing with HR+ (MCF7) breast cancer cell lines.

Cell lines were propagated according to ATCC. MS forming protocol consisted on cell culturing in DMEMF12 supplemented with bFGF and EGF. Media was renewed every 2 days. Flow cytometry analysis, with antibodies anti-CD44, anti-CD24 and anti CD133 was made.

Microscopic observation showed a differential phenotype. HR+ cells formed spherical colonies in suspension while TN maintained adherent appearing only a few groups of MS. This may be related with late recurrence.

Controls of both cell lines analyzed showed a low CD44 markup. For both cell lines CD133 did not show significant changes. HR+ cells had higher expression of CD44 and CD133 when compared with TN.

In TN cells was identified 2 populations of cells in suspension. The major one was CD44+ and in 1\% this expression was even more relevant and may be representative of a progenitor cell population. The HR+ showed stronger staining for CD24 than TN. The HR+ also differentiated 2 populations, a major one CD44+

\footnotetext{
* Correspondence: mcandido@fmed.uc.pt

${ }^{1}$ Biophysics/Biomathematics Institute/IBILI, Faculty of Medicine, University of Coimbra, Coimbra, Portugal

Full list of author information is available at the end of the article
}

and 9\% with minor expression of CD44. The results suggest a significant fraction of HR+ harboring CD44+, representing a phenotype of progenitor cells.

\section{Author details}

${ }^{1}$ Biophysics/Biomathematics Institute/IBILI, Faculty of Medicine, University of Coimbra, Coimbra, Portugal. ${ }^{2}$ Gynaecology Service, University Hospitals of Coimbra, Coimbra, Portugal. ${ }^{3}$ Center of Histocompatibility of the Center, Coimbra, Portugal. ${ }^{4} \mathrm{CIMAGO}$, Faculty of Medicine, University of Coimbra, Coimbra, Portugal.

Published: 24 September 2010

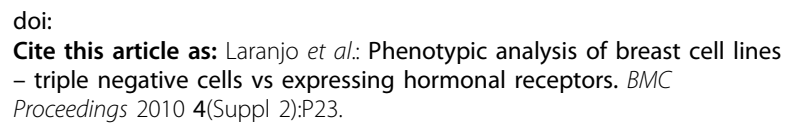

Submit your next manuscript to BioMed Central and take full advantage of:

- Convenient online submission

- Thorough peer review

- No space constraints or color figure charges

- Immediate publication on acceptance

- Inclusion in PubMed, CAS, Scopus and Google Scholar

- Research which is freely available for redistribution

Submit your manuscript at www.biomedcentral.com/submit
C Biomed Central 